\title{
Los comerciantes franceses en Castilla y la Represalia de 1667
}

\author{
Juan A. Sánchez BelÉn * \\ María Dolores Ramos Medina
}

Desde que en 1585 Felipe II resolviera promulgar el bloqueo económico a Inglaterra y Holanda, al mismo tiempo que emprender contra ambas naciones una guerra ofensiva, idea propugnada con insistencia por el cardenal Granvela, aunque nunca antes aceptada por completo ', los monarcas españoles recurrieron siempre a esta práctica en caso de conflicto bélico, a pesar del impacto negativo que pudiera tener en la actividad económica de sus súbditos, convencidos de que este recurso era tanto o más efectivo que las acciones militares desarrolladas en el campo de batalla. A partir de entonces, pues, fueron numerosos los planes que se formularon y adoptaron en Madrid para combatir al enemigo en el terreno comercial, según se evidencia en el decreto Gauna de 1603 o en las órdenes ejecutadas en el reinado de Felipe IV, dirigidas a neutralizar el poder naval y mercantil de Holanda y, posteriormente, a bloquear el comercio de Francia, Portugal e Inglaterra ${ }^{2}$. Sin duda, el contrabando de mercancías de las potencias extranjeras beligerantes - y de España también- realizado por buques de naciones neutrales limitó el alcance de los bloqueos comerciales, máxime cuando los mercaderes españoles contravenian a menudo las disposiciones decretadas en la Corte y la Corona

* UNED. Madrid.

Gómez-CENTURión, C. . Felipe II, la empresa de Inglaterra y el comercio septentrional (15661609). Madrid 1988, págs. 87 y ss.

2 Dominguez Ortiz, A., "Guerra económica y comercio extranjero en el reinado de Felipe IV", Hispania, XXIII, 1963, págs. 70-110; ECheVARria BacigaluPE, M.A., "Un episodio en la guerra económica hispano-holandesa: el decreto Gauna (1603)", Hispania, XLVI, 1986, págs. 57-97; Alcalá-Zamora y Queipo de Llano, José, España, Flandes y el Mar del Norte (1618-1639). La última ofensiva europea de los Austrias Madrileños. Barcelona 1975, págs. 115-116; ISRAEL, Jonathan 1., The Dutch Republic and the Hispanic World, 1606-66. Oxford 1989, págs. 80-95, 204-222, 282-298. 
se veía incapaz de abastecer con productos nacionales la demanda americana. De aquí, por tanto, que entre 1638 y 1650 se concedan licencias a los franceses para comerciar sus géneros en los dominios de Felipe IV a cambio de una suma de dinero que, en 1638, importó 255.400 ducados de plata ${ }^{3}$. Aun así, la acción de las naves corsarias españolas, financiadas a veces por el rey, ocasionaron daños cuantiosos al enemigo, en particular las que operaban en el Atlántico, y cuya base principal era el puerto de Dunkerque, seguido, ya en la Península, por los de San Sebastián y Fuenterrabía ${ }^{4}$.

La prohibición de comercio era, por supuesto, con todas sus desventajas, la medida de guerra económica más importante que tenían en sus manos los estados soberanos de la Europa Moderna. Junto a ella aparece con frecuencia, especialmente en el siglo xvII, la represalia contra los bienes de los súbditos de las naciones en conflicto bélico. En España este arbitrio adquirió un cierto relieve y continuidad al menos tras la intervención de Francia en la Guerra de los Treinta Años, en 1635, no obstante que desde 1626 se venía practicando con regularidad ${ }^{5}$. Las excepciones a esta norma por causas diversas (naturalización de los mercaderes extranjeros, concesión de indultos, etc.) y la ocultación de bienes susceptibles de ser embargados reducian los beneficios que esperaban obtenerse con este procedimiento, si bien el daño infligido era considerable. Dos ejemplos permiten hacernos una idea del efecto económico de semejante recurso. En 1635 sólo el valor de los bienes embargados a los franceses importó a las arcas del tesoro cerca de 1.000 .000 de ducados. De otra parte, un informe elaborado en 1664 por un comité inglés estimaba en 1.500.000 libras las pérdidas que habían sufrido los mercaderes ingleses desde 1660 por multas, impuestos especiales y confiscaciones decretadas por la Corona española ${ }^{6}$.

3 Alcalá-Zamora y Queipo de Llano, J., Op. cit., págs. 178-183; Girard, Albert, Le commerce français a Seville et Cádix au temps des Habsbourg. Contribution a l'étude du commerce etranger en Espagne aux XVle et XVIle siécles. París 1932, págs. 77-89 y 165-186.

${ }_{4}$ Stradling, R.A., "The Spanish Dunkirkers, 1621-1648. A record of plunder and destruction», Tidjahift voor Geschiedenrs, 93, 1980, págs. 541-558; BAETENS, R. “Organisation et resultats de la course flamande au XVlle siecle», Revue des Amis du vieux Dunkerque, VI, 1983, págs. 47-78; Otero LANA, Enrique, Los corsarios españoles durante la decadencia de los Austrias. El corso español del Atlántico peninsular en el siglo xvII (1621-1697). Madrid 1982.

5 AHN, Consejos Suprimidos, leg. 7269. Consulta del Consejo de Castilla de 1702 informado sobre las represalias decretadas desde 1626 en adelante.

6 AHN, Estado, leg. 871; BNM, Mss., 11030, fols. 279-380. Relación de la Hacienda por Tomás de Aguilar; StRADLING, R.A., Europa y el declive de la estructura imperial española, 15801720. Madrid 1981, págs. 220 y ss. Para el embargo a los holandeses, IsRAEL, J.I., «Spain, the Spanish embargoes and the struggle for the mostery of World Trade, 1585-1600", en Empires and Entrepots. The Dutch, the Spanish Monarchy and the Jewes, 1585-1713. London 1990, págs. 189-212. 


\section{ORIGEN DE LA JUNTA DE REPRESALIAS DE 1667}

Los preparativos militares que el rey Cristianísimo llevaba a cabo en el mes de mayo de 1667 en las proximidades de los Países Bajos sujetos a la obediencia de Madrid alertó a los ministros de doña Mariana sobre una posible invasión, aun cuando la diplomacia francesa manifestara una y otra vez la voluntad de su soberano de no romper el tratado de los Pirineos firmado en 1659. De hecho, el Consejo de Castilla, en respuesta a un decreto de la regente de 23 de mayo de 1667, esboza una serie de providencias que deben prevenirse ante un eventual ataque de Francia, incluyendo, obviamente, la represalia contra las haciendas de los franceses, aunque desestima su promulgación inmediata con el argumento de que Luis XIV podría acogerse a este pretexto para iniciar una ofensiva bélica, empero que el apoyo prestado a los portugueses en su independencia venía a ser como una declaración de guerra ${ }^{7}$. Tales precauciones sirvieron de poco, pues en el mes de julio, sin previo aviso, las tropas francesas penetran en los Países Bajos españoles, reclamados por Luis XIV como herencia de su esposa la infanta María Teresa de Austria, hija de Felipe IV ${ }^{8}$, conquistando varias plazas fronterizas, iniciándose así el primer enfrentamiento armado hispano-francés del reinado de Carlos II.

Tamaña tropelía exigía de Madrid una respuesta contundente en el plano militar y político, pero también en el económico. No obstante, doña Mariana de Austria se muestra indecisa en declarar la guerra a Francia, temerosa quizás de las maniobras que en el interior pudiera realizar en beneficio propio don Juan José de Austria ${ }^{9}$. Mas las dudas de la regente se disipan pronto. El 10 de julio de 1667 dirige al Consejo de Castilla un decreto ordenándole que disponga todo lo necesario para asegurar al reino del enemigo y causar a los franceses residentes en Castilla utodas las hostilidades $i$ daños que se pudiere de cualquier manera $i$ en cualquier forma", incluyendo la promulgación de una represalia, sobre cuya ejecución y conveniencia solicita su parecer al Consejo ${ }^{10}$. El 14 de julio la reina gobernadora declara oficialmente la guerra y al día siguiente el Consejo de Castilla le informa de haber comunicado a las autoridades locales la nueva solución bélica a fin de prevenir los medios más adecuados para la defensa del reino. Respecto a la represalia, su dictamen es el de eje-

\footnotetext{
7 AHN, Consejos Suprimidos (Consejos), leg. 7169, Consulta del Consejo de Castilla, 25 de mayo de 1667 y Real Decreto de 23 de mayo de 1667.

8 Sobre este episodio, Maura, Duque de, Vida y reinado de Carlos II. Madrid 1959, tomo I.

- Para este personaje, ver CASTILla Soto, Josefina, Don Juan José de Austria (hijo bastardo de Felipe $(V)$ : su labor política y militar. Madrid 1990.

$10 \mathrm{AHN}$, Consejos, leg. 7269. Real Decreto de 10 de julio de 1667.
} 
cutarla sin demora, publicándola en todos los puertos, ciudades, villas y lugares de cada reino, sean de realengo, señorío o abadengo. Esta propuesta es defendida unánimemente por los consejeros, quienes, de forma sistemática, explican, punto por punto, las razones que les han inducido a plantearla con el propósito firme de eliminar el recelo que parecía mostrar la regente en aplicarla. Así, se argumenta que la represalia no vulnera los capítulos de la Paz de los Pirineos, ni siquiera el capítulo veinticuatro que estipulaba conceder un plazo de seis meses de término a los súbditos de ambas potencias signantes para abandonar los reinos y transportar sus propiedades libremente a donde quisieran instalarse, ya que, en esta ocasión, el rey Cristianísimo ha decretado de forma unilateral la represalia contra los españoles en sus dominios poco después de iniciar las hostilidades $y$, además, nunca ha cumplido los acuerdos del Tratado, en particular el de abstenerse de ayudar a Portugal, a quien ha socorrido con dinero, gente, buques y asesoramiento militar ${ }^{11}$.

Soslayando los argumentos políticos que justificaban este proceder contra los franceses, el Consejo de Castilla no ignoraba los beneficios que podrían obtenerse con su ejecución ni el perjuicio que acarrearía al comercio que mantenían en España y América, toda vez que desde el Tratado de los Pirineos habían ido adquiriendo una posición destacada al amparo de la cláusula de nación más favorecida, equiparando sus privilegios a los obtenidos por sus rivales mercantiles en anteriores acuerdos, sobre todo los holandeses, que disfrutaban de ventajas especiales en algunos ramos del comercio, de lo que protestaban continuamente los embajadores de Francia en Madrid por el agravio que recibian ${ }^{12}$. También los Consejos de Estado y Guerra fueron partidarios de dicho medio por idénticas consideraciones. De este modo, doña Mariana de Austria convoca el 2 de agosto de 1667 una Junta Particular integrada por don Juan de Góngora, D. Antonio de Monsalve y el Conde de Villaumbrosa, para estudiar la forma que debería adoptarse en el embargo de las haciendas de los franceses.

La Junta Particular, en su consulta del cuatro de agosto, aconseja sin ambigüedad que se ejecute la represalia atendiendo fundamentalmente a las ganancias que puede deparar al tesoro por la presencia abrumadora,

AHN, Consejos, leg. 7269. Consulta del Consejo de Castilla, 15 de julio de 1667.

2 Girard, A., Op. cit., págs. 396-397; IsRaEL, J.I., The Dutch Republic and the Hispanic World, 1606-1661. Londres 1982, págs. 412-434; Domínguez OrTIz, A., Op. cit., págs. 104; KAMEN, H., La España de Carlos II. Barcelona 1980, págs. 178, 181, 188, 209-210; ABReu Y Bertolano, J.A., Tratado de paz con España. Reinado de Felipe IV. Madrid 1751, tomo VII, págs. 112 y ss. 
a su juicio, de súbditos franceses en las principales plazas mercantiles del reino, como Cádiz, Sevilla, Málaga, Puerto de Santa María, Sanlúcar de Barrameda, Antequera, Bilbao, San Sebastián, La Coruña y Madrid, sin contar las pertenecientes a la Corona de Aragón y Navarra. Tras esto recomienda la creación de una Junta de represalias a quien se encomiende todo lo relativo al embargo, siguiendo el modelo diseñado por la Real Cédula de 23 de junio de 1635, y que tendrá que estar constituida por ministros de todos los consejos, incluido el de Indias, pues si bien los franceses están excluidos del comercio indiano, como cualquier otro extranjero, las concesiones de naturaleza otorgadas facultándoles para dicha actividad hacen aconsejable su presencia en la Junta para defender los intereses de su competencia. Sugiere asímismo se prohiba el comercio con Francia en conformidad con la Real Cédula de 12 de julio de 1635 y se muestra partidaria de imponer una contribución especial a los franceses que se encuentren en los dominios de la Monarquía, según lo dispuesto en la Real Cédula de 8 de diciembre de 1638 e instrucción del Consejo de Castilla de 9 de diciembre del mismo año, dado que, al parecer, este servicio reportó a las arcas de la Real Hacienda unos 50.000 ducados anuales. Mientras se crea la Junta de Represalias, y para ganar tiempo, propone que se elabore una Instrucción con las normas fijadas el 15 de junio de 1635, a las que se añadirán varios aspectos que entonces no se tuvieron en cuenta: examen de los seguros marítimos y de los registros de los cargamentos con destino a América para conocer el nombre de los beneficiarios de las mercancías y caudales remitidos desde allí a la península, sobre todo los que son de franceses; supervisión, a la llegada de la Flota y Galeones, de los libros de los maestros plateros con el objeto de impedir trasvases fraudulentos de plata; reconocimiento de los géneros que entran en las aduanas, con noticias de sus propietarios y destinatarios, así como de los factores y correspondientes de los mercaderes franceses; por último, averiguación de los créditos que éstos tienen con los hombres de negocios de Madrid, Sevilla y otras plazas financieras españolas. Todas estas disposiciones deberán comunicarse por "vía secreta" a los virreyes y gobernadores en Indias con el intento de obstaculizar el encubrimiento de géneros y plata embarcados hacia España con destino a súbditos de Francia, pero también a los virreyes de los restantes reinos y a los corregidores de las ciudades cabeza de partido o provincia de la costa andaluza y cantábrica, para que los ejecuten «provisionalmente", sin esperar a que se constituya la Junta de Represalias, porque el asunto es tan importante que «no permite aguardar a formali- 
dades ni Juntas, porque en cualquier hora se aventura mucho en la ocultación de escripturas y otros efectos" ${ }^{13}$.

\section{CREACIÓN DE LA JUNTA DE REPRESALIAS}

La lentitud burocrática de la Monarquía Hispánica, unido al deseo de la regente de obrar del mejor modo y, presumiblemente, al interés particular de los cargadores -en agosto de 1667 zarpa de Cádiz el convoy de don Agustín Odiostegui cargado de azogue y otros géneros hacia América ${ }^{14}$ - impiden la rápida aplicación de la represalia como aconsejaba la Junta Particular. Es cierto que el veinticuatro de julio se publica en Pamplona, procediendo su virrey de inmediato a los embargos ${ }^{15}$ mas también es verdad que el nueve de agosto el virrey de Valencia, marqués de Leganés, recibe la orden de proceder a la confiscación de las haciendas de franceses en su jurisdicción -en esta fecha se enviaron despachos de aquel tenor a los corregidores ${ }^{16}-$, y sabemos que hasta después de pasados quince días no lo puso en práctica, permitiendo que el asunto se divulgase y que las personas afectadas pudieran desprenderse a tiempo de sus bienes ${ }^{17}$. Tal demora, sin embargo, no puede achacarse sólo a la negligencia de las autoridades que gobernaban los reinos y provincias; la ausencia de una Real Cédula que autorizara expresamente la represalia les maniataba. Lo mismo acontecía con la prohibición de comercio con Francia, pues aunque el 14 de julio se resuelve enviar a los veedores de contrabando de los puertos la órdenes impartidas en anteriores conflictos armados, y que en algunos lugares se ha procedido a decomisar los géneros llegados de aquel país, todavía el nueve de agosto el Consejo de Guerra se ve precisado a demandar a la reina que promulgue el oportuno decreto de prohibición de comercio con Francia ${ }^{18}$.

13 AGS, Guerra Antigua (G.A.), leg. 3495. Consulta de la Junta Particular (...) para la disposición y prevenciones con que se debe executar la represalia de bienes de franceses (...). 4 de agosto de 1667.

14 Morineau, Michel, Incroyables gazettes et fabulaux metaux. Les retours des tresois americaius d'aprés les gazzettes hollandaises (XVle-XVIlle siècles).Cambridge 1985, pág. 279, tableau 45 .

15 AGS, G.A., leg. 3525. Consulta de la Junta de Represalia, 18 de septiembre de 1670.

16 AHN, Consejos, leg. 7269 Real Decreto y Provisión de 9 de agosto de 1667.

17 Garcia Martinez, Sebastián, Valencia bajo Carlos //. Valencia 1991, pág. 294. Este autor da como fecha del bando publicado en Valencia el día 22 de agosto, pero posiblemente se trate de un error de transcripción del documento o de imprenta. De ser auténtica la fecha, reforzaría nuestra hipótesis de que el secreto con que se pretendía efectuar la represalia y su coordinación en todo el ámbito de la Monarquía fracasó rotundamente.

18 AGS, G.A. leg. 3495. Consulta del Consejo de Guerra, 9 de agosto de 1667. 
No será hasta el veintiuno de agosto cuando se ponga en marcha el dispositivo del embargo, una vez creada la Junta de Represalias, a cuyos ministros se remite la consulta de la junta Particular del cuatro de agosto para que, atendiendo a su contenido, proponga lo que debe disponerse y observarse en la confiscación de las haciendas de franceses ${ }^{19}$. El Conde de Ayala, miembro del Consejo de Estado; el marqués de Aguilafuente, del Consejo de Guerra; Antonio Ferrer que pertenece al Consejo de Aragón; Marcelino Marchán, del de Italia; Antonio de Castro, del de Indias; Simón Ferlants, del Consejo de Flandes y, por último, Antonio de Monsalve, miembro del Consejo de Castilla desde 1664, constituyen una junta que, con jurisdicción privativa en todos los dominios de la Corona española, es concebida como órgano supremo para el gobierno y dirección del embargo de bienes y haciendas de franceses, a la vez que tribunal de apelación en primera y segunda instancia para todos los pleitos incoados en Madrid, así como de apelación en segunda instancia en causas fuera de la Corte, llegando de esta forma solamente los pleitos de mayor cuantía, esto es, para la Corona de Castilla superiores a treinta mil maravedies y para los demás reinos superior a sesenta mil maravedies, siendo los de menor cuantía fenecidos ante los mismos jueces que las iniciaron. A través de la Junta se consultará a la Reina lo que fuese necesario, y por via de gobierno se ordenará todo lo que se tuviese por más conveniente para la dirección y ejecución de este negocio. Al mismo tiempo se concede jurisdicción exclusiva en materia judicial para cualquier tema de represalia, siendo tribunal en última instancia. A pesar de ello, habrá obstáculos que provocarán grandes retrasos en la ejecución del proceso de represalia contra bienes e intereses franceses en suelo español.

En efecto: en su primera reunión, convocada el 26 de dicho mes, y en ausencia del marqués de Aguilafuente, D. Antonio de Monsalve y Marcelino Marchán, se notifica a doña Mariana de Austria haber recibido todos los documentos despachados pero no ofrecen una resolución, tal vez por no estar presentes algunos de sus componentes. Con todo, ese mismo día se publica la prohíbición de comercio con Francia, incluyendo la Instrucción elaborada en 1635, donde se recogen las pautas que deberán seguir los ministros en sus respectivas demarcaciones. No se adopta, en principio, la imposición de un tributo especial a la colonia francesa como ocurrió en 1638, por estimarse inoportuno ahora ${ }^{20}$, si bien más adelante se decreta, ya que en una consulta del Consejo de Castilla se alude a la

AGS, G.A., Leg. 3495. Real Decreto de 21 de agosto de 1667.

20 AGS, G.A., Leg. 3495, Consulta de 2 de noviembre de 1667. 
pretensión del cónsul francés, Pedro Catalán, de que los mercaderes de su nación no paguen "lo que resta de satisfacer» "21. Tras estas gestiones se ordena al Marqués de Fuente el Sol que efectúe el cobro de la "farda" en la ciudad de Sevilla, siempre y cuando se haga con el mayor cuidado para no perjudicar la paz que se ajustará ${ }^{22}$.

En cuanto a la represalia propiamente dicha, el veintisiete de agosto la Junta ya constituida elabora una normativa general que será el material con el que se podrá levantar el edificio del embargo ${ }^{23}$, incorporando la «Instrucción» publicada en 1635 y que ahora se amplía hasta treinta y una disposiciones recogiendo otros apartados que ayudarán a la "mayor comprobación y averiguación de las haciendas que perteneciesen a franceses" ${ }^{24}$.

De otro lado, el nombramiento, meses más tarde, de los oficiales que compondrian el personal de la Junta (fiscal, relator, tesorero, contador y escribano de Cámara) origina un largo y arduo proceso. Tras una primera consulta en 14 de septiembre de 1667, donde se propone como fiscal a don Pablo Juárez, como tesorero a don Francisco Manzano y como contador a don Juan González de Zárate surgen entre la Junta y doña Mariana de Austria serias divergencias. El día 28 de septiembre aquella defiende, contra el parecer de la reina, que el fiscal fuera ministro político y no togado. El procedimiento seguido para la elección de los oficiales era la propuesta de una terna. La Junta, a tenor de lo dicho, resolvió proponer para tal oficio a don Pablo Juárez, don Francisco de Palacios y don Tomás de Iz. Normalmente tras la propuesta se ofrecía un período por el cual

21 AHN, Consejos, leg. 7119. Consulta del Consejo de Castilla, 13 de septiembre de 1668. El Consejo de Castilla tiene noticias de los problemas que está causando la aplicación de la "farda" en Sevilla, donde el cónsul francés en aquella ciudad se niega a que los súbditos del rey Cristianismo paguen lo que quedaron a deber del impuesto sobre los franceses residentes en la Península.

22 AHN, Cons, Leg. 7199, Consulta del Consejo de Castilla de 13 de septiembre de 1668.

23 BNM, Varios Especiales (V.E.) 64-69. "Instrucciones..." compuestas de veinticuatro apartados relativos a la forma de ejecutar la represalia, recogidas íntegramente en el documento expedido el día 26 de agosto de 1667. (Ver Abreu y Bertolano, Joseph de, Colección de Tratados de paz de España. Reinado de Carlos II, Tomo I (1665-1673). Madrid 1751, págs. 251 y 252) ampliándose hasta treinta y uno supuestos en un documento publicado al día siguiente, 27 de agosto, que serían las Instrucciones definitivas que dirigirían los pasos a seguir en el embargo e incautación de bienes y caudales de franceses en los territorios de la Corona española en 1667 .

${ }^{24}$ BNM, V.E., 64-69. Real Decreto expedido en junio de 1635 recogiendo las Instrucciones del día 26 de junio de 1667, Ver Abreu y Bertolano, Joseph Antonio de, Opus cit., págs. 236255; BNM, Mss, 8180. Real Decreto de 27 de agosto de 1667 e «instrucciones..." fols. 3-9. Este documento ya contiene las treinta y una instrucciones por las que se regirán los sucesivos embargos decretados por la Corona durante la segunda mitad del siglo xVII. 
alguno de los miembros de la Junta podían presentar ternas alternativas. Este sería el caso del marqués de Aguilafuente que propuso a don Diego Solano, juez de quiebras, don Pablo Juárez y don Luis Cerdeño, abogado de los consejos.

En cuanto a los restantes oficios, el mecanismo era el mismo. Para la provisión de relator se propuso a don Gaspar Cortés, relator del Consejo de Guerra, don Diego de Angulo, relator del Consejo de Indias, y don José de Torres. Al respecto, el Marqués de Aguilafuente propuso los mismos sin preferencias. Para el oficio de tesorero fueron presentados don Francisco Manzano, tesorero del Consejo de Guerra y de las Haciendas del Contrabando, don Diego de Arce, tesorero de las Indias y don Juan Imbonats, tesorero de Flandes. Como en casi todas las provisiones de oficios en las instituciones de la época moderna, la Junta aconsejaba que el designado diera una fianza por valor de 10.000 ducados. En otros documentos relativos a nombramientos municipales o relatores los designados a estos cargos tenían obligación de presentar fianza por un valor parcial del oficio que fueran a ocupar. Para el cargo de contador se presentó proposición de nombramiento en las personas de don Juan González de Zárate contador general de Justicia del Consejo de Guerra y de las Haciendas del Contrabando, contador de título y oficial mayor de la Contaduria de relaciones del Consejo de Hacienda y a don Francisco Castillo. En este caso, uno de los ministros, don Antonio de Castro propuso a don Juan González de Zárate, don Pablo de Benavente y don Pedro Moguer de Morales. Por su parte el marqués de Aguilafuente aconsejó el nombramiento de don Juan González de Zárate, don Pablo de Benavente y don Pedro Moguer de Morales.

Para el oficio de escribano será propuesta una terna entre los que destacaba don Juan de Miranda. La decisión sobre algunas provisiones a estos ofícios provocará retrasos, como sucedió el día 30 de noviembre de 1667, cuando la Junta anuncia que ninguno de los tesoreros propuestos ha sido aceptado, por lo que al respecto se habla con don Angel Garretón, que no había figurado en ninguna terna, y finalmente el oficio recaerá en don Juan González de Zárate y el de contador en don Pablo de Benavides. Al año siguiente, en consulta de 25 de enero de 1668, se disponen los horarios - reuniones los miércoles y viernes por las tardes-. Rápidamente se ven ampliadas a los lunes por la tarde, ante el retraso que hay en los expedientes y salarios de sus componentes. La Junta asume esta breve obligación pero no deja de expresar a la reina que no depende tanto de su diligencia el pronto despacho de los pleitos como de la lentitud de los tribunales ordinarios, pues al ser tribunal de apelación en última instancia sólo puede actuar cuando se ha dictado sentencia en primera y segunda instancia. Precisamente este factor será decisivo en la 
ejecución de la represalia, jugando en contra del eficaz proceso de localización y embargo de las propiedades de los franceses.

\section{INSTRUCCIONES PARA EL EMBARGO Y REPRESALIA DE BIENES Y CAUDALES DE FRANCESES EN TERRITORIOS DE LA CORONA ESPAÑOLA EN 1667}

Las instrucciones publicadas el día 27 de agosto de 1667 tienen su origen en la consulta del día 4 de ese mismo mes, donde la Junta particular ofrecía como una de sus primeras conclusiones la elaboración de una Instrucción general cuyo contenido venía ya recogido en otra anterior publicadas el 15 de junio de 1635 - con motivo de la ejecución en aquel año de la represalia contra franceses-, ampliándose ahora con las reales cédulas del día 4 de junio de 1635, incorporada en el artículo primero, y que disponía se ejecutara la represalia el mismo día y a la misma hora, notificándose a todos los corregidores y justicias del reino-, así como con la cédula de 25 de junio de ese mismo año, ordenando a los escribanos que dieran fe de los clientes de nación francesa cuyas escrituras aparecían en sus protocolos. Hasta aquí, lo expuesto reproducía las instrucciones publicadas el día 26 de agosto de 1667, pero el documento definitivo refrendado un día después iba más allá, insertando algunos puntos relativos a la localización de las haciendas de los franceses en Indias.

Sabemos por la misma consulta del día 4 de agosto que la Instrucción de 1635 fue difundida por todo el territorio de la Corona, también en Indias ${ }^{25}$, mas lo que se cuestiona, a la vista de la documentación consultada, es la eficacia en su aplicación, ya que ese documento no controlaba los instrumentos ni el mecanismo para la localización de las haciendas de franceses, debido fundamentalmente a que los registros oficiales ocultaban los verdaderos intereses económicos de las naciones extranjeras, tanto en la Península como en las Indias. En efecto, la ampliación recogida en las Instrucciones de embargo del día 27 de agosto de 1667 hacía referencia al reconocimiento de diferentes documentos mercantiles, tanto públicos (alcabalas, libros de los registros de aduanas y puertos, cartas de naturaleza, registros de las salidas y retornos de las

${ }^{25}$ AGS, G.A., Leg. 3495. Consulta de la Junta particular de 4 de agosto de 1667 , donde se recogía la noticia del envío a través del consejo de Indias de la Real Cédula de 15 de junio de 1635 a Indias. El contenido del documento enviado se recoge en BNM, V.E., 64-69. "Instrucciones en la forma en que se ha de executar el embargo, y repressalia, que su Magestad ha mandado hazer en los bienes, y hazienda de franceses, que se hallaren en todos sus reinos, y señorios". 15 de junio de 1635. 
flotas), como privados (correspondencia localizada en estafetas, libros de las "Confianzas" de los maestres de la plata, libros de los hombres de negocios de Madrid y Sevilla, así como de otras ciudades, documentos crediticios, y "confianzas" que había en poder de los compradores de plata de Sevilla), para ser utilizados por los ministros de cada distrito como instrumentos necesarios para una mejor y más exhaustiva localización de los súbditos franceses con intereses en el comercio indiano. $Y$ es que la situación reflejada en las Instrucciones nos habla de una realidad económica donde el alto índice de ocultaciones y simulaciones era moneda corriente, debido, en gran medida, a la publicación de pragmáticas de prohibición de comercio y represalia que fueron una constante en las relaciones entre ambas coronas, al menos, durante esta centuria, colocando los intereses económicos franceses en una situación de interinidad, a lo que contribuía el monopolio al que se veía sometido el comercio indiano obstruyendo cualquier tipo de participación ulegal» extranjera. Todo ello facilitaba que las ocultaciones y simulaciones fueran un medio frecuente utilizado por las naciones extranjeras dedicadas a la actividad mercantil, consolidando de esta forma su presencia en el comercio español e indiano, en este período.

El contenido definitivo de la instrucción de 1667 establece, en primer lugar, los mecanismos para la localización de bienes de franceses, delimitando los campos de actuación legal donde se encontraban los objetos de embargo, bien a nombre de los súbditos de esa nación o de españoles ${ }^{26}$ que estuviesen en posesión de propiedades francesas, representando intereses de aquella nación ${ }^{27}$. De los primeros sabemos que podían conseguir el estatuto de «naturales» a través de dos vías: el matrimonio y mediante la expedición de cédulas de naturaleza. En este último caso, los súbditos del rey Cristianísimo en posesión de este documento sufrirían el embargo, y solamente tras la presentación de la documentación acreditativa se les excluiría del mismo ${ }^{28}$, provocando, no obstante, numerosos pleitos. Ante esta situación los que no conseguían ulegalizar su actividad mercantil" mediante los mecanismos antecedentes, cuando las circunstancias internacionales no les permitían ejercer el comercio directo en suelo español recurrían a corresponsales y factores. Por esta razón era

2s BNM, Mss. 8180. Instrucciones, art. 12; ABREU y BertOlano, Joseph de, Opus cit, págs. $251-52$, artículo $X$, sobre los naturales que ejercen como correspondientes y factores ya que serán objeto de la misma diligencia, esto es, aplicación de los artículos II-IX, siempre teniendo presente no causar molestia algunos a súbditos de estos reinos. Cédula de 26 de agosto de 1667 e instrucciones.

27 BNM, Mss, 8180. Instrucciones, art. 1.

28 Ibidem, art. 20. 
frecuente que muchos de los bienes e intereses franceses estuvieran camuflados bajo nombres de naturales del reino.

En segundo lugar, la Instrucción determina el personal encargado de llevar a efecto las diligencias de la represalia, siendo el ministro superior en cada distrito el responsable de su ejecución, cuya primera función será localizar los franceses que residen en su distrito ${ }^{29}$, para lo que se servirá de los medios que tuviera a su alcance. En segundo lugar, su labor se centrará en elaborar un inventario, para lo que se requiere su presencia, al menos en una primera fase de localización de las haciendas, y así, no sólo, constatar la fiabilidad del proceso sino también garantizar la ausencia de fraudes. Los inventarios elaborados ante notario deberán llevar la rúbrica del ministro de la represalia, nombrado en cada distrito ${ }^{30}$. En los casos que los bienes embargados lo aconsejasen se dispondrá de un especialista en materias diversas. Por último, tras el embargo el ministro deberá elegir una persona encargada de custodiar los bienes incautados, también denominado "depositario de los bienes de la represalia" ${ }^{31}$, que fuese de toda confianza. El trabajo realizado por los ministros no estaba remunerado ${ }^{32}$ y no podían intervenir, tampoco sus familiares bajo pérdida de todo lo adquirido además de las otras penas ${ }^{33}$.

La elaboración de un inventario es el primer paso incluido en la Instrucción de 1667 para poner en práctica la represalia de franceses, declarando con claridad las "cantidades y calidades" de lo que fuera objeto de embargo, así como especificando el modo de llevarlo a efecto, no sólo sobre los bienes de franceses, sino también dando noticia de los libros de negocios de los factores y encomenderos españoles, que serán del mismo modo inventariados. Para una elaboración eficaz de este documento empleará personal especializado que ofrezca la tasación más fiel del valor real de lo incautado, ya que de ello depende la obtención de importantes beneficios económicos para las arcas reales.

La tipología de los bienes objeto de incautación es variada. En principo se menciona el dinero en efectivo, así como joyas, plata labrada, alhajas, bienes muebles e inmuebles, si los hubiere, asi como mercancías en lonjas y tiendas de comerciantes. Pero tan importante como los primeros es un segundo tipo de objetos de incautación: nos referimos a libros de con- 
tabilidad o cualquier otro documento mercantil (escrituras de poder, obligación, débitos, letras) que, más que proporcionar caudales propiamente dichos, ofrecen una importante información adicional para la localización de un mayor número de personas con intereses entremezclados en las comunidades extranjeras, y que en principio podrían haber sido ignorados, ante la inexistencia de otro tipo de fuente de información, poniendo en conocimiento de las autoridades competentes todo el entramado de relaciones mercantiles y de "hermandad" existentes entre los miembros de las comunidades extranjeras y, en muchos casos, sus relaciones personales con la comunidad mercantil autóctona.

La importancia de los documentos incautados provocó que se incluyeran en esta normativa, para la ejecución correcta y eficaz de la represalia, unos requisitos necesarios para la elaboración del inventario de los libros de los hombres de negocios, ya que estos documentos debían tener rubricadas todas sus hojas por el notario, el ministro de la represalia del distrito correspondiente, así como en la mayoría de los casos por el veedor del contrabando, siendo los siguientes pasos los más comunes en la inventarización de ellos: en primer lugar se enumerarán las hojas, si no lo estuvieran, y se signarán por el ministro a cargo de la represalia, junto con el escribano para que no se pudiese alterar ninguna de las partidas represaliadas, declarándose también los folios en blanco que se rayarían con líneas que los atravesaran de parte a parte en prevención de posibles alteraciones. A esta primera incautación le seguirá la de las escrituras, letras de cambio, y otros papeles sueltos, que también se anotarán en el inventario ${ }^{34}$, dictaminando con ello lo que convenga ejecutar en adelante como consecuencia de la amplia información recibida a través de estos documentos. Por último se registrará la correspondencia encontrada en los escritorios de los mercaderes franceses. Toda esta documentación se obtendrá de las bibliotecas o lugares de negocio (lonjas, tiendas o casastiendas) donde los comerciantes tengan recogida su documentación mercantil. A fin de obviar abusos o reclamaciones posteriores este material informativo será inventariado, en presencia de los interesados o sus apoderados así como ante el cónsul de la nación, en caso de que lo hubiese.

Pero si importante era la confección de los inventarios, cruciales para localizar las haciendas y bienes de franceses, el descubrimiento de estos súbditos, de los que no se conocía su número exacto, era aún más importante si cabe. Por ello se necesitaba recurrir a todo tipo de medios que proporcionaran datos de esta colonia en las distintas circunscripcio-

34 Ibidem, art. 8. 
nes. Así, al repertorio informativo obtenido por los ministros de la represalia se unen otras dos formas de averiguación: las declaraciones, adjuntas a los inventarios, de toda persona allegada (criados, vecinos) o que estaban en contacto a través de sus negocios con la comunidad mercantil francesa (otros hombres de negocios, factores, y corresponsales naturales o extranjeros), así como también las declaraciones efectuadas por los escribanos, a los que mediante los decretos correspondientes se les obligaba a presentar una relación, en el plazo de tres días, de las escrituras de franceses que tuvieran registradas en sus protocolos. Por último la Instrucción va más allá invitando a todas las personas que tuviesen haciendas o bienes de franceses de cualquier tipo a que los declarasen ante notario en un plazo de tres días, bajo pena de pagar el doble en caso negativo. También se publica que quienes diesen favor y ayuda a franceses para ocultar algunos bienes, o interviniesen en la ocultación de ellos y se hallasen en su poder, serían gravemente castigados ${ }^{35}$ en sus personas, en primer lugar con la pérdida de toda su hacienda para después aplicarles las demás penas en que hubieren incurrido por derecho, como gratificando a los que declarasen quienes tenían en su poder hacienda de franceses concendiéndoles la décima parte de lo que cobraren ${ }^{36}$. Si hubiera, gracias a todas las gestiones, noticias de bienes en otros reinos o distritos se dará conocimiento de ello a los ministros de la Junta de represalias para que por la vía correspondiente promulgue las órdenes oportunas.

Otro capítulo que aborda la Instrucción es la venta de los objetos represaliados. Esta se hará en pública subasta o almoneda, estableciendo plazos en función de la naturaleza de lo confiscado. En un primer momento se venderán las cabalgaduras y cualesquiera animales y bienes que produjeran gastos o pudieran fácilmente deteriorarse. Lo mismo se obrará en el caso de tratarse de embarcaciones estipulándose que las de más de cien toneladas y artillería queden reservadas a la Corona, no pudiendose vender las restantes a extranjeros, como tampoco se autoriza enajenar ningún bien sin haber sido ante notario ${ }^{37}$. La venta además deberá reunir una serie de requisitos imprescindibles para que sea transparente: no admitir en la puja a ministros que hubieran intervenido en la represalia o familiares y allegados suyos, bajo la pena de perder todo lo comprado, aparte de serles aplicadas las sanciones que se decidirá imponerles. Aquellas mercancías que por su naturaleza no fuera necesario 
vender rápidamente o fuera conveniente esperar a una mejor coyuntura, se regula que pasen a manos del depositario de los bienes de represalia, quien se encargará de su custodia hasta el momento de la venta ${ }^{38}$.

Finalmente, la Instrucción abordaba un aspecto de suma importancia: el trato que se debía dar tanto a los súbditos franceses, sujetos al proceso de incautación, como a los españoles que representaban sus intereses. En cambos casos, serán tratados con la máxima corrección, poniendo gran cuidado en no causar vejaciones de ningún tipo a los primeros, ni molestias a los segundos ${ }^{39}$, algo que numerosas veces la Corona española procuró siempre que se observase, a lo menos en el siglo XVIII ${ }^{40}$. Esto tal vez explique la lentitud con que se llevaron a efecto los inventarios, pues el veintisiete de octubre, y en respuesta a un Real Decreto fechado el día anterior, la Junta comunica a la reina la imposibilidad de enviar relaciones de lo obrado hasta entonces porque los ministros delegados en las capitales de provincia y de partido no los habían remitido. Por esta razón, y ante estos problemas, en consulta del día 14 de octubre de 1667, se sugiere que, para reforzar la Instrucción dada a los corregidores, se publique un bando donde se incentive a los delatores, aumentando las recompensas a una cuarta parte del valor de los bienes confiscados y no a una décima parte. Con todo, tenemos constancia que en la elaboración de los inventarios, por lenta que fuera, se seguía muy de cerca las recomendaciones que aparecían en la Instrucción objeto de nuestro análisis.

\section{LA ACTUACIÓN DE LA JUNTA DE REPRESALIAS}

La publicación de la Real Cédula de 26 de agosto de 1667 ordenando la represalia contra la hacienda de los franceses en todo el territorio de la Monarquía Hispánica, acompañada de la Instrucción correspondiente, y que fue divulgada en las principales ciudades y villas mediante bandos entre los días veintiocho y veintinueve de agosto ${ }^{41}$, algún tiempo después de haber iniciado Luis XIV las hostilidades en los Países Bajos españoles, no tuvo los efectos deseados por los ministros de la reina gobernadora. En primer lugar, una considerable proporción de mercancías de Francia había partido para América en los galeones de don Martín de Bañuelos,

38 Ibidem, art. 24.

39 Ibidem, arts. 17 y 20.

40 SALAS AUSENS, J.A., “La inmigración francesa en Aragón en la Edad Moderna", Estudios de Historia Moderna. Zaragoza 1985-86, págs. 70-71.

41 AHN, Alcaldes de Casa y Corte (A.C.C.), libro 1252, fols. 143-145. 
que zarparon de Cádiz el día 3 de marzo de 1667, y otra cantidad, probablemente, fuese embarcada con igual destino en los navíos que transportaban azogue a cargo de don Agustín de Odiostegui ${ }^{42}$. Por otro lado, la colonia francesa estaba advertida desde hacía bastantes meses de las intenciones de la soberana y pudo así desprenderse de parte de sus bienes, poniéndolos a nombre de terceras personas, en lo que se vio favorecida además por los rumores que corrían de una inminente represalia. La Sala de Alcaldes de Casa y Corte lo pone de manifiesto cuando notifica al Consejo de Castilla que los mercaderes franceses habían vendido sus propiedades a otros comerciantes, los cuales, no disponiendo de dinero en efectivo, les habían otorgado letras de pago ${ }^{43}$. A su vez, la Junta de Represalias informaba a la reina de las ocultaciones de estos bienes en las viviendas de personajes influyentes en la Corte, aun siendo súbditos de Luis XIV, como el señor de Santoné, que al morir en este mismo año de 1667 deja una fortuna valorada en 130.000 ducados, cuando no en las casas de los mercaderes de otras nacionalidades incluidos los españoles, en las dependencias de los embajadores o en las posadas de los cónsules residentes en las ciudades portuarias ${ }^{44}$. Así, por ejemplo, en el mes de agosto, por denuncia del fiscal de la aduana de Cádiz, se embargó en las casas de Daniel Van den Tempel siete frangotillas con platillas de Holanda y pelo de camello, junto con otros géneros, propiedad de Diego Luis de la Parra, aparte de cuarenta y seis piezas de holandas sin despacho de la aduana y varias joyas destinadas a Pedro Esminsart, vecino de Sevilla ${ }^{45}$.

El estamento eclesiástico tampoco permaneció al margen de este proceso de poner a recaudo pertenencias y géneros de franceses. De sobra es conocida su participación en la venta fraudulenta de artículos de consumo sujetos al pago de las sisas reales y municipales ${ }^{46}$. No puede sorprender, en consecuencia, que ahora hiciesen lo mismo protegiendo mercancías vedadas por la Corona. Una denuncia del obispo de Cádiz advierte que en su diócesis, y más en concreto en la ciudad, varios conventos acogen estos artículos obstaculizando la represalia, cuando no las pesquisas, de los veedores de contrabando nombrados por estas fechas para impedir el desembarco de géneros venidos de Francia en los

42 Morineau, Michel, Opus cit, pág. 279, tableaux 45.

AHN, A.C.C., libro 1252, fol. 165.

AGS, G.A., Leg. 3506. Consulta de la Junta de Represalias, 20 de mayo de 1668.

5 AGS, G.A., leg. 3503. Consulta del Consejo de Guerra, 1 de agosto de 1667.

46 SÁNCHEZ BELÉN, J.A., "La represión del fraude fiscal a finales del siglo XVII: La Junta de Fraudes, 1682- 1687". Actas del ll Congreso de la Asociación de Historia Moderna. Murcia 1993, págs. 519-534; KAMEN, H., Op. cit pág. 
puertos españoles ${ }^{47}$. Parecidos impedimentos encontraron los ministros delegados de la Junta de Represalias en la averiguación y embargo posterior de bienes de franceses en poder de los penitenciarios del Santo Oficio, si hemos de creer los avisos de don Francisco de Gálvez sobre la dificultad de proceder contra ellos en Llerena ${ }^{48}$.

Más aun, los ministros de la Junta de Represalias, a pesar de tener jurisdicción privativa en esta materia, tuvieron con frecuencia que enfrentarse a las ingerencias de otros tribunales, como le sucedió a varias Juntas del reinado de Felipe IV y de Carlos II, surgiendo conflictos de competencias que impedían llevar a cabo con éxito las directrices emanadas de la reina ${ }^{49}$. De ello se queja la Junta en una consulta de 3 de septiembre de 1668. En esta ocasión se denuncian las maniobras dilatorias de los ministros del Consejo de Aragón para confiscar y convertir en dinero las propiedades de los franceses residentes en Valencia, Cataluña y Aragón. Precisamente, el príncipe de Esquilache, virrey de Aragón, advierte a la reina sobre los peligros que existen en el reino, mal defendido y con una poderosa colonia francesa que puede levantarse en armas de ejecutarse la orden de secuestro de sus bienes, lo que puede explicar aquí la lentitud de los embargos, tanto como las quejas de la Diputación del Reino, contraria a esta medida por sus consecuencias en el abastecimiento y comercio de sus naturales ${ }^{50}$. Asimismo, el 1 de marzo de 1668, la reina comunica al presidente del Consejo de Castilla que ordene a los oidores de la Audiencia de Sevilla no intervengan en los autos incoados por el Conde de Humanes y menos todavía en que indulte a los infractores a cambio de una suma corta de dinero ${ }^{51}$.

También los corregidores fueron acusados de tales prácticas, y meses antes se informó a doña Mariana de Austria de las intromisiones de la Chancillería de Granada admitiendo recursos de los afectados contra los ministros delegados de la Junta de Represalias ${ }^{52}$. Dicho tribunal llega

47 AHN, Consejos, leg. 7119. Consulta del Consejo de Castilla, 4 de noviembre de 1667; AGS G.A., leg. 33492. Consulta de la Junta de Represalia de 18 de noviembre de 1667.

48 AGS, G.A., Leg. 3504. Informe de don Francisco de Gálvez, 17 de diciembre de 1667.

49 Gelabert, Juan, "El impacto de la guerra y del fiscalismo en Castilla", La España del Conde-Duque de Olivares.Valladolid 1990, págs. 556-573; SÁNCHEz BELÉN, J.A., “Absolutismo y Fiscalidad en Castilla: El encabezamiento General del Reino, 1683-1685", Espacio, Tiempo y Forma. Madrid, serie IV, n. 2,1989 , págs. 186 y ss.

50 AGS, G.A., Leg. 3506. Consulta de la Junta de Represalias de 5 de septiembre de 1668; BNM, V.E., 28/78; Girard, A., Op. cit, pág. 260.

51 AHN, Consejos, leg. 7269, Real Decreto de 1 de marzo de 1668

52 AGS, G.A., Leg. 3516, Consulta de la Junta de 28 de julio de 1668 y leg. 3516 y Consulta de la Junta de Represalias, 20 de febrero de 1668. 
incluso a confiscar el producto obtenido de la venta de bienes de los franceses residentes en Alcalá la Real y que el corregidor de la ciudad, don Diego Antonio de Ovando, enviaba a la Corte por conducto del depositario que había nombrado a tal efecto ${ }^{53}$. En los territorios bajo dominio señorial, en donde asimismo debía ejecutarse la represalia, los ministros encontraron iguales, si no mayores, dificultades en ejercer su cometido. Basta como muestra lo acontecido en la villa de Cuevas, uno de los lugares más conflictivos en asuntos relacionados con el contrabando de mercancías de todo tipo ${ }^{54}$. Aquí el alcalde mayor de la ciudad de Vera, don Luis Ximénez, comisionado por la Junta, no ha podido acometer el embargo porque el alcalde de la localidad, licenciado Juan Muñoz, le denegó el uso de la comisión que llevaba, y además comboyó hasta la costa a los franceses del lugar y sus mercancías para que no pudiera actuar contra ellos. De poco debió de servir que la Junta solicitara -y obtuviese - autorización para procesar el encubridor, prendiéndole, pues es muy posible que recurriera a la Chancillería de Granada, o incluso al Consejo de Castilla, originándose un litigio de competencias entre jurisdicciones que no estaría resuelto hasta después de firmarse la paz con Francia, quedando impune el transgresor o, todo lo más, sancionado levemente ${ }^{55}$.

Los ministros de la Junta tuvieron que hacer frente, por otro lado, a los veedores del Contrabando. Un caso, entre muchos, es el que se desarrolla en Cádiz, donde el juez del contrabando, marqués de Fuente el Sol, se opone a don Diego de Ibarra por haber requisado una barra y cuatro piñas de plata por valor de $3.106,5$ pesos, aparte de varios géneros, que remitía desde Tanger, en "El comboy de Holanda», el correspondiente en esta ciudad del mercader francés Diego de Cartería. Al final, y pese a las protestas de la Junta de Represalias, doña Marina de Austria ordena que se remitan los autos de Ibarra al marqués de Fuente el Sol y la plata, o su valor en dinero, a Andrea Piquinoti, depositario de gastos secretos, retirándolo de la Tesorería de la Junta en la Corte a donde había sido transferido ${ }^{56}$.

La Instrucción del 27 de agosto de 1667 preveía además el embargo de los bienes de franceses naturalizados en España, si bien a los que presentasen cédula de estar en posesión de cartas de naturaleza para

Ibidem, leg. 3516. Consulta de la Junta, 15 de junio de 1668.

54 AGS, C.J.H., leg. 1506, Consulta del Consejo de Hacienda, 3 de agosto de 1687.

55 AGS, G.A., legs. 3506 y 3513. Consulta de la Junta, 5 de marzo de 1668.

56 AGS, G.A., Leg. 3506. Consulta de la Junta, 20 de febrero de 1668 y 23 de marzo de 1668. 
comerciar en estos reinos y en América, en el ínterin en que la Junta resolvía lo más conveniente, se les permitía conservar sus haciendas, dando para ello las fianzas oportunas y comprometiéndose a tenerlas "en forma de depósito". Esta medida, sin contar los fraudes que podía generar, originó, como cabía suponer, una avalancha de reclamaciones, en parte porque, a tenor de lo que la Instrucción alude, se habían otorgado en los últimos años demasiadas cartas de naturaleza a súbditos de Fran$\mathrm{cia}^{57}$. Para hacernos una idea del volumen de reclamaciones, y su efecto en la dinámica de gobierno de la Junta, es suficiente recordar que el 19 de abril de 1668 un Real Decreto urge a este tribunal a que agilice la resolución de los pleitos y poco después se ordena que en los de escasa cuantía se llegue a algún ajuste con la parte querellante ${ }^{58}$. En general, la solución arbitrada en estos pleitos fue la del indulto, consistente en desembargar las propiedades y demás bienes de los franceses a cambio de abonar éstos una suma de dinero proporcionada al valor de la hacienda confiscada, una vez tasada. El cuadro I sintetiza este tipo de indulto.

\section{CUADRO}

RELACIÓN DE ALGUNOS INDULTOS AJUSTADOS CON SÚBDITOS DE FRANCIA

\begin{tabular}{|c|c|c|c|c|}
\hline Nombre & Nacionalidad & Vecindad & Bienes confiscados & Indulto \\
\hline Álvarez Mesa, Manuel & Portugués ${ }^{(1)}$ & - & $\begin{array}{l}\text { Mercancias por } \\
65.000 \text { reales/Von }\end{array}$ & 9.000 reales/von \\
\hline Amoras, Juan de & Aragonés (2) & Sevilla & - & $4.400 \mathrm{reales} /$ Von \\
\hline ANGAES, Pedro & - & Soria & - & 3.300 reales $/$ Von \\
\hline BEADOC, Francisco & Francés & Daimiel & $\begin{array}{l}\text { Hacienda por } \\
1.400 \text { reales } / \text { Von }\end{array}$ & 600 reales $/$ Von \\
\hline Bonol, Esteban & Saboyano ${ }^{\{3\}}$ & Pastrana & $\begin{array}{l}\text { Hacienda por } \\
3.500 \text { reales } / \text { Von }\end{array}$ & 500 reales $/$ Von \\
\hline CaBALLero, Honorato & Francés & Mondejar & $\begin{array}{l}\text { Tienda buhonero } \\
\text { (Madrid) }\end{array}$ & 400 reales $/$ Von \\
\hline Casanova, Juan de & Francés ${ }^{\text {(4) }}$ & - & - & 5.500 reales $/$ Von \\
\hline Castel, Pedro & Francés & Daimiel & 一 & 1.100 reales/Von \\
\hline Corragloso, Agustín & Saboyano ${ }^{(3)}$ & Madrid & Bienes de franceses & 6.600 reales $/$ Von \\
\hline Desiento, Baltasar & Francés & Madrid ${ }^{(5)}$ & - & - \\
\hline $\begin{array}{l}\text { FraconET, Jacques } \\
\text { Gulo, Juan y Antonio }\end{array}$ & Francés & Torrelaguna & $\begin{array}{l}\text { Tienda de sombreros } \\
\text { Haciendas en } \\
\text { memorias pias }\end{array}$ & $\begin{array}{c}700 \text { reales/plata } \\
\text { (5) }^{(5)}\end{array}$ \\
\hline HEON, Guillermo & Francés & $\begin{array}{l}\text { Jerez de la } \\
\text { Frontera }\end{array}$ & $\begin{array}{l}\text { Haciendas de } \\
\text { campo (5 bis) }\end{array}$ & 6.600 reales $/$ Von \\
\hline Primet, Antonio & Francés & Valladolid ${ }^{(6)}$ & $\begin{array}{l}\text { Hacienda por } \\
21.000 \text { reales/Von }\end{array}$ & 6.600 reales/Von \\
\hline
\end{tabular}




\begin{tabular}{|c|c|c|c|c|}
\hline $\begin{array}{l}\text { Santa Cruz, Salvador } \\
\text { Ser, Bernardo y Fco. } \\
\text { Splas, Fco. de }\end{array}$ & $\begin{array}{l}\text { Francés } \\
\text { Franceses } \\
\text { Francés }\end{array}$ & $\begin{array}{l}\text { Sevilla }^{(7)} \\
\text { Pastrana } \\
\text { Huete }\end{array}$ & $\begin{array}{l}210.000 \text { reales/Von } \\
\qquad- \\
\text { Retazos extremeños } \\
\text { y un caballo }\end{array}$ & $\begin{array}{r}42.000 \text { reales } / \\
8.800 \text { reales } \\
\text { Valor todd } \\
1.210 \text { reales } / V \epsilon\end{array}$ \\
\hline ELES & Navarro ${ }^{(9)}$ & Soria & - & $3.300 \mathrm{re}$ \\
\hline
\end{tabular}

Fuente: A.G.S.G.A. Leg. 3506 y 3513.

NOTAS: (1) Se le embargan porque son mercancias procedentes de Francia. (2) Hay dudas en la Junta de su origen aragonés. Por eso se le embarga. ${ }^{(3)}$ No sabemos porque se actúa contra él, aunque posiblemente por qué posee géneros de Francia. ${ }^{(4)}$ Tiene carta de naturaleza dada por Felipe IV en 1664. ${ }^{(5)}$ Al ser criado de S.M. se le desembargan sus bienes, como se hiciera con Juan Rugero, cirujano oculista. ${ }^{(5 \text { bis })}$ En una relación de 25/8/68 de bienes embargados en Jerez, figura Guillermo Heón con propiedades tasadas sólo en 400 reales/vellon. A.G.S.G.A. Leg. 3514. ${ }^{(6)}$ Los testamentarios se comprometen a pagar 7.835 reales, pero al final se desembargan las haciendas. ${ }^{(7)}$ Arrendador de millones del consumo de Sevilla. Lo que se le embarga es la fianza. El pago lo realizan los testamentarios porque Salvador de Santa Cruz ha fallecido. ${ }^{(8)}$ Son reputados por naturales de Castilla, viviendo en Pastrana 45 y 36 años, respectivamente, habiendo desempeñado cargos de justicia. (9) Se dice que es de la Sexta Merindad de Navarra y ha ejercido oficios públicos y la depositaria del servicio de quiebra de millones.

La dificultad mayor de los ministros de la Junta en las reclamaciones presentadas fue la de comprobar en todos los casos si las personas a las que se embargaron sus bienes eran o no naturales de Francia. Desde luego, ésta era una labor ingente que no cabía acometer con los medios disponibles entonces. Por eso se procedió sumariamente contra todos aquellos que el vulgo consideraba franceses. Después habría tiempo para comprobarlo mediante los documentos aportados por las personas afectadas. Es lo que se hace, por ejemplo, con Claudio Mesquie, el cual, para recuperar su hacienda, aporta un documento de Juan Claudio Fallot, agente de Beçanson, en el que se dice que el susodicho mercader es natural de la villa de Mirecur, en el ducado de Lorena, vasallo, por tanto, del emperador ${ }^{59}$.

La Junta de Represalias, sin embargo, no abordó sólo las reclamaciones de súbditos franceses, estuviesen o no naturalizados en España; también tuvo que atender las demandas de los españoles y de vasallos de otras naciones a causa, fundamentalmente, de que en su poder se encontraban géneros procedentes de Francia, letras de cambio emitidas por franceses o mercancías de éstos que habían ocultado en sus casas. No olvidemos que tales supuestos aparecian recogidos en la Instrucción del 27 de agosto de 1667, recomendando la reina gobernadora a los ministros que velasen su cumplimiento, para lo cual admitirían incluso denuncias en secreto, retribuyendo a los denunciantes con una suma proporcionada al valor de las mercancías y propiedades vendidas en subasta pública ${ }^{60}$.

59 AGS, G.A., Leg. 3506. Consulta de la Junta, 2 de marzo de 1668.

60 BNM, Mss. 8180, fols. 3- 9 . 
A Juan del Campo, por ejemplo, se le confiscan sus bienes, no por ser francés, que lo es aunque naturalizado en Castilla, donde lleva viviendo veintiocho años - se dedica a la fabricación de ladrilos para las caballerizas del Pardo y las obras del Buen Retiro-, sino porque, según la Junta, ha ocultado géneros de Francia ${ }^{61}$. Carlos del Rey, secretario del embajador de Holanda, es otro de los afectados por la represalia, ya que estaba en posesión de unas mercancías que le había dado Carlos Hermant, arquero del rey, en pago de cierta cantidad de dinero que le adeudaba, y en opinión de la Junta tales géneros deberían considerarse de franceses ${ }^{62}$. Curioso es asimismo el ajuste realizado con Agustín Corregioso, natural de Turín y vecino de Madrid. Su hacienda, distribuida entre Madrid y Segovia -esta última a nombre de don Juan de Liaño- es embargada fundamentalmente porque un tal Antonio Sadoc, francés, le había dado poder para cobrar unas joyas y otros efectos de Bartolomé Balbour, poder que, no obstante, había traspasado a Luis Hurtado, contra quien se sigue un pleito en el que Corragioso se ve envuelto a su pesar. En ningún caso -así se dice - se le embargan sus bienes por haber tenido tratos con franceses mediante la creación de una compañía mercantil, disuelta poco antes del estallido de la guerra ${ }^{63}$.

Estos ejemplos nos permiten vislumbrar la compleja trama de relaciones sociales y mercantiles tejida por los mercaderes oriundos de Francia, muchos de los cuales se sirven de españoles o mantienen tratos con naturales de otros reinos amigos de la Monarquía Hispánica. Una tupida red que, como la de los portugueses del reinado anterior ${ }^{64}$, se imbrica en todas las esferas de la vida nacional gracias a los matrimonios con españolas, integrándose en las localidades donde residen hasta perder su conciencia de extranjeros, llegando en ocasiones a alcanzar posiciones de prestigio en esa sociedad que les ha acogido, como Juan de Velaster, afincado en Soria, que ha desempeñado, al parecer, oficios públicos en la ciudad ${ }^{65}$ y el cargo de depositario del servicio de quiebra de millones y quien, a pesar de asegurar que es natural de la Sexta Merindad de

61 AGS, G.A., Leg. 3506. Consulta de la Junta, de 2 de marzo de 1668.

62 Ibidem, leg. 3506. Consulta de la Junta de 25 de mayo de 1668.

63 Ibidem, leg. 3506. Consulta del Consejo. 25 de mayo de 1668.

64 BRoEns, Nicolás, Monarquía y capital mercantil: Felipe $N$ y las redes comerciales portuguesas. Madrid 1989; BoYAJIAN, J.C., Portugueses Bankers and the Court of Spain (1626- 1650). New Jersey 1983; SANZ AYAN, C., Los banqueros de Carlos II. Valladolid 1988.

65 Sobre los requisitos exigidos por la legislación castellana para ocupar cargos municipales ver CASTILlo de Bobadilla, J., Política para corregidores y señores de vasallos. Amberes 1704, ed. facsimil. Madrid 1978, libro III, Capítulo VIII; Nueva Recopilación de las leyes de España, libro VII/I y VII/III. 
Navarra, opta por pagar un indulto de 300 ducados de vellón, lo cual, en cierta medida, viene a cuestionar, cuando menos, sus origenes navarros ${ }^{66}$. Análoga integración social hallamos en Juan de Guío, vecino de Torrelaguna, ya fallecido: después de vivir cuarenta años en la villa y contraído en ella matrimonio, destina toda su hacienda para fundar memorias de misas perpetuas y cofradias en el lugar, posiblemente -el documento no lo especifica - con el propósito de beneficiar, a título de capellán o beneficiario, a su sobrino Antonio Guío ${ }^{67}$.

Por lo que se refiere a mercancías de franceses en manos de mercaderes españoles, la Corona determina que en el plazo de tres días éstos informen a los ministros de la Junta de los géneros que tienen para registrarlos, sancionándoles, en caso contrario, con el pago del doble de su valor, aparte de cualesquiera otras penas que se decida imponerles ${ }^{68}$. A pesar de esta disposición varios mercaderes se abstuvieron de acudir a los registros, motivo por el cual fueron multados con el 5 por ciento del importe de los géneros tasados - nunca se llegó a aplicar la sanción estipulada ${ }^{69}$ - Tampoco observaron la obligación de vender las mercancías procedentes de Francia en el plazo de cuatro meses a partir de la Real Cédula de 27 de agosto de 1667. En particular, los comerciantes que traficaban con tejidos de seda, tanto en Madrid como en Valencia y Sevilla, solicitaron que se les prorrogase el plazo otorgado para venderlos, pues no lo habían podido realizar porque en invierno nadie usaba tales artículos, especialmente chamelotes y tafetanes. La reina, oído el parecer de la Junta de Represalias y del Consejo de Guerra, que fue quien estableció el citado plazo, se aviene a concederles tres meses más para enajenar dichos géneros, no obstante que la Junta había insistido en que convenía acelerar su venta, ya que, mientras se hallasen en poder de los mercaderes este tipo de mercadurías, se favorecería el contrabando por la dificultad de determinar si tales tejidos estaban en las tiendas antes de la ruptura de las hostilidades con Francia ${ }^{70}$.

\section{VALOR DE LA REPRESALIA Y CONSECUENCIAS PARA EL COMERCIO FRANCÉS}

¿A cuánto ascendió el importe de la represalia de 1667 ? Por una relación que acompaña una consulta de la Junta de Represalias, fechada

66 AGS, G.A., leg. 3506. Consulta de la Junta de 7 de septiembre de 1668 y consulta de 28 de septiembre de 1668, donde se ofrece análoga situación.

67 Ibidem, leg. 3506. Consulta de la Junta. 28 de septiembre de 1668.

68 BNM, MSs. 8180. Instrucciones, artículo 15.

69 AGS, G.A., leg. 3504. Consulta del Consejo de Guerra. 14 de noviembre de 1667

70 AGS, G.A., leg. 3506. Consulta de la Junta, 13 de abril de 1668 y 8 de mayo de 1668; leg. 3513. Consulta de la Junta, 11 de mayo de 1668. 
el 26 de noviembre de 1668, el valor total de los embargos realizados en Castilla, señorío de Vizcaya y Navarra alcanzó la cifra de 311.440 reales de plata y 421.506 reales de vellón, sin contar otros 124.454 reales de vellón y 967 reales de plata que estaban en poder del tesorero de la Junta y 10.591 reales de plata y 8.344 reales de vellón que habian sido directamente transferidos a Juan Imbonets ${ }^{71}$. Una cifra francamente desproporcionada respecto a la colonia francesa establecida en Castilla, aun cuando quedaran fuera del secuestro los bienes de los mercaderes naturalizados en el reino. Sólo en Cádiz, por ejemplo, se contabiliza en un padrón de 1662 unos veintisiete franceses, cuyo número en 1670, según un informe de Pedro Catalán, se reduce a veintiuno. Cierto es que este grupo gaditano es el que contribuye en mayor proporción, por cuanto que suscribe con la Corona el pago de 212.000 pesos o reales de a ocho a modo de indulto para que no se embargue la plata y mercancía que viene de América en los galeones de Tierra Firme al mando de don Manuel de Bañuelos y en la Flota de Nueva España bajo las órdenes del marqués de Villarrubia ${ }^{72}$. Con todo, esta cantidad probablemente no hiciese honor al caudal que venía a nombre de franceses, a tenor de los datos consulares relativos al año 1671, en el que partieron de Cádiz veintidós embarcaciones francesas cargadas con metal precioso por valor de 3.826 .000 pesos, además de los artículos en especie ${ }^{73}$. Desde luego, atendiendo a los datos elaborados por Michel Morineau a partir de la documentación holandesa y francesa, los galeones comandados por don Manuel de Bañuelos fueron considerados en la época «mucho más ricos que los precedentes", estimándose su carga en 18.000 .000 de pesos, aunque el registro oficial redujo esta cifra a 11.000 .000 de pesos. A esta cargazón hay que añadir los 10.000 .000 de pesos - valor estimado - que traía la Flota de Nueva España y que atracó en Cádiz en agosto de 1667, en pleno conflicto bélico ${ }^{74}$.

Todo parece indicar, pues, que el esfuerzo de la reina gobernadora y sus consejeros para colapsar el comercio francés en los circuitos mercantiles de la Monarquía Hispánica no logro su propósito: los indultos dejaban a disposición de los mercaderes el beneficio obtenido en el tráfico indiano, y no tenemos noticia alguna de que se adoptaran represalias

71 Ibidem, leg. 3506. Consulta de la Junta de 26 de noviembre de 1668 y leg. 3516. Informe del secretario de la Junta, 17 de abril de 1667.

${ }_{72}$ AGS, G.A., leg. 3506. Consulta de la Junta, 26 de noviembre de 1668; GIRAhD, A., Op. cit. pág. 259, nota 82 , págs. 260 y 272.

73 Kamen, H., La España de Carlos II. Barcelona 1981, págs. 217

${ }^{74}$ Morineau, M., Op. cit, págs. 231, nota 39 y 233. 
contra las grandes firmas francesas, como las de Pedro Magán, Tomás de la Haya, Pedro Tranchant, Francisco Belin, Pedro Grut y Antonio Barbier, entre otros. Más todavía, del indulto general al comercio gaditano hubo que exceptuar, devolviéndole su aportación (1.400 pesos), a Simón Solet, quien demostró estar naturalizado ${ }^{75}$. Esto, por supuesto, referido a Castilla, si bien es preciso indicar que la fuente localizada no nos ha brindado demasiadas noticias sobre este particular. Por ejemplo, los datos disponibles sobre los embargos de bienes de franceses se limitan a localidades pequeñas del interior peninsular (Cuenca) o ciudades andaluzas con poco tráfico (Jerez de la Frontera, Alcalá la Real); nunca se refieren a grandes núcleos mercantiles, y financieros como Madrid, Bilbao, San Sebastián, Cartagena, Cádiz, Puerto de Santa María y Sevilla, pues de los puertos y ciudades de la Corona de Aragón y del reino de Navarra no disponemos por ahora de datos al no haber podido consultar sus archivos.

\begin{tabular}{|c|c|c|c|c|}
\hline \multicolumn{5}{|c|}{$\begin{array}{c}\text { CUADRO ॥ } \\
\text { NÓMINA DE MERCADERES DE MÁLAGA A QUIENES SE HAN } \\
\text { EMBARGADO GÉNEROS DE FRANCIA }\end{array}$} \\
\hline Nombre & $\begin{array}{l}\text { Nacionali- } \\
\text { dad }\end{array}$ & Categoria & Domicilio & Merc. Embargada \\
\hline ANDRÉs, Francisco & - & mercader joyas & C/ San Juan & $\begin{array}{l}\text { peines de boj, espejos } \\
\text { pequeños, puntas, estu- } \\
\text { ches, tijeras, sortijas de } \\
\text { bronce. }\end{array}$ \\
\hline ARJONA, Diego de & - & especiero & C/ San Juan & $\begin{array}{l}\text { estuches, peines de boj, } \\
\text { cuchillos, cordones de } \\
\text { hilo, cintas de cuero, an- } \\
\text { teojos, rosarios de palo, } \\
\text { flautas, alfileres, goma } \\
\text { arábiga, alquitira. }\end{array}$ \\
\hline $\begin{array}{l}\text { CÁRDENAS, Diego } \\
\text { FrancisCo }\end{array}$ & - & mercader joyas & C/ San Juan & $\begin{array}{l}\text { estuches, peines de boj, } \\
\text { navajas. }\end{array}$ \\
\hline CarLos, Felipe & - & mercader joyas & C/ San Juan & estuches. \\
\hline & - & especiero & Pza. Espederas & $\begin{array}{l}\text { estuches, navajas, pei- } \\
\text { nes, coralillos colorados. }\end{array}$ \\
\hline $\begin{array}{l}\text { CASTILLO, Ricardo } \\
\text { del }\end{array}$ & - & $\begin{array}{l}\text { mercader por } \\
\text { menor }\end{array}$ & C/ Nueva & oreas. \\
\hline CEA, Juan de & - & Idem & Idem & oreas. \\
\hline $\begin{array}{l}\text { CERDA, M. Jeróni- } \\
\text { mo de la }\end{array}$ & - & Idem & Idem & oreas. \\
\hline $\begin{array}{l}\text { DíAZ, Luis Francis- } \\
\text { co }\end{array}$ & - & mercader joyas & C/ San Juan & $\begin{array}{l}\text { navajas, estuches, tije- } \\
\text { ras, rosarios de palo, cu- } \\
\text { chillos, puntas de Lore- } \\
\text { na. }\end{array}$ \\
\hline
\end{tabular}

75 Lantery, Raimundo de, Memorias..., ed. Manuel Bustos Rodriguez. Cádiz, 1983, págs. 89; Girard, A., Op. cit. pág. 259, nota 82, 260 y 272; Garcia Fuentes, L., El comercio español con América: 1650-1700. Sevilla 1980, pág. 157. 


\begin{tabular}{|c|c|c|c|}
\hline Duarte, Manuel & - & especiero & C/ Granada \\
\hline EsLEBA, María de & - & mercadera & C/ Nueva \\
\hline $\begin{array}{l}\text { ESPINO, Mateo José } \\
\text { de }\end{array}$ & - & $\begin{array}{l}\text { mercader por } \\
\text { menor }\end{array}$ & C/ Nueva \\
\hline $\begin{array}{l}\text { Gallardo, María } \\
\text { (viudad) }\end{array}$ & - & $\begin{array}{l}\text { mercadera por } \\
\text { menor }\end{array}$ & C/ Nueva \\
\hline ÓMEZ, Jerónimo & - & & C/ San \\
\hline
\end{tabular}

$\begin{array}{llll}\begin{array}{l}\text { Grandes, Francis- } \\ \text { Co }\end{array} & - & \begin{array}{l}\text { mercader por } \\ \text { HuRtado, Pedro }\end{array}- & \text { C/ Nueva } \\ \text { mercader } & \text { P.a de la Mar }\end{array}$

$\begin{array}{llll}\begin{array}{l}\text { HuRTADO DE CASTI- } \\ \text { LLA, Juan }\end{array} & - & \begin{array}{l}\text { mercader por } \\ \text { menor }\end{array} & \text { C/ Nueva } \\ \text { lBaRRA, Francisco } & - & \begin{array}{l}\text { mercader por } \\ \text { menor }\end{array} & \text { C/ Nueva } \\ \text { JoRge, Pedro } & - & \begin{array}{l}\text { especiero } \\ \text { espanta Maía }\end{array}\end{array}$

$\begin{array}{llll}\text { JUSTICIA, Sebastián } & - & \begin{array}{l}\text { mercader } \\ \text { menor }\end{array} & \text { C/ Nueva } \\ \text { LÓPEZ dE LA CERDA, } & - & \text { Idem } & \text { Idem } \\ \text { Diego } & & \\ \text { LópEZ HURTADO, } & - & \text { especiero } & \text { P. del Mar } \\ \text { Francisco } & & & \end{array}$

$\begin{array}{lll}\text { Maldonado, Pedro } \quad-\quad \text { especiero } & \text { C/ Cuatro } \\ & \text { Esquinas de } \\ & \text { los Moros }\end{array}$

cordones, tijeras, estuches, goma arábiga, incienso de almaciga, almaciga.

oreas (leona, cordelera) y bretañas.

oreas (leona, cordelera), alonas, macayres (sic) bretañas.

oreas (anchas y angostas), bretañas y macayres.

peines finos, estuches, tijeras, navajas, rosarios de palo, guantes de castor.

oreas y estameñas.

candados, estuches, navajas, gaitas de París, cintas del pelo, cordones de Paris, peines, estampas de papelón de Francia, tijeras, tranchetes, bisagras y aldabillas, relojes de brújulas, hilo de color, goma arábiga, coralillos falsos, alquitira. oreas (anchas y angostas).

oreas cordeleras.

navajas, estuches, espejos, alfileres, escarmendadores de hueso, cuchillos, lentejuelas de plata, cordones, rosarios, ladrillos de jabón piedra. peines, goma arábiga, almaciga, alquitira, hilo.

orea angosta, alona, macayres.

orea angosta.

candados, navajas (ordinarias y con cabos de carey), estuches (ordinarios y finos), peines, espejos, pitos, flautas, láminas de vitela, cordones, agujetas, cuchillos de Francia, almáciga alquitira, goma, arábiga, hilo.

espejos de librea, anteojos, gaitas de París, goma arábiga, alquitira. 


\begin{tabular}{|c|c|c|c|c|}
\hline MARTIN, Blas & - & especiero & C/ San Juan & $\begin{array}{l}\text { estuches, navajas, flau- } \\
\text { tas, rosarios de palo, re- } \\
\text { licarios de plomo, tijeras, } \\
\text { alfileres, peines, cintas, } \\
\text { cuchillos, cordones, } \\
\text { goma arábiga, alquitira. }\end{array}$ \\
\hline Noriega, Fernando & - & $\begin{array}{l}\text { mercader por } \\
\text { menor }\end{array}$ & C/ Nueva & $\begin{array}{l}\text { oreas (anchas y angos- } \\
\text { tas), bretañas, alonas. }\end{array}$ \\
\hline OCAMPO, Catalina & - & mercadera & C/ Nueva & $\begin{array}{l}\text { oreas angostas, macay- } \\
\text { res. }\end{array}$ \\
\hline Oliveras, Pedro & - & mercader & C/ Nueva & $\begin{array}{l}\text { oreas (anchas y angos- } \\
\text { tas), macayres. }\end{array}$ \\
\hline $\begin{array}{l}\text { ORTIZ, } \\
\text { (viuda) }\end{array}$ & - & $\begin{array}{l}\text { mercadera por } \\
\text { menor }\end{array}$ & C/ Nueva & $\begin{array}{l}\text { oreas (angostas), breta- } \\
\text { ñas, ruanes, alonas, co- } \\
\text { tonias, macayres. }\end{array}$ \\
\hline PESSO, Jacinto & - & - & 一 & $\begin{array}{l}\text { navajas, tijeras, rosarios } \\
\text { de palo, estampas, es- } \\
\text { tuches ordinarios, cor- } \\
\text { dones de hilo, botones } \\
\text { de hilo de plata falsa, } \\
\text { sombreros blancos y de } \\
\text { castor, bretañas. }\end{array}$ \\
\hline $\begin{array}{l}\text { PRADOS, Jacinta } \\
\text { (viuda) }\end{array}$ & - & mercadera & C/ Nueva & $\begin{array}{l}\text { oreas angostas, breta- } \\
\text { ñas, cotonias. }\end{array}$ \\
\hline PUERTO, Andrea del & - & mercader joyas & C/ San Juan & $\begin{array}{l}\text { estuches, puntas de Lo- } \\
\text { rena. }\end{array}$ \\
\hline Prudencio, José & - & especiero & P. ${ }^{a}$ de la Mar & $\begin{array}{l}\text { candados pequeños, re- } \\
\text { dondos, chatos, estu- } \\
\text { ches, alquitira. }\end{array}$ \\
\hline $\begin{array}{l}\text { RAMIREZ DE ASUA, } \\
\text { Juan }\end{array}$ & - & $\begin{array}{l}\text { mercader por } \\
\text { menor }\end{array}$ & C/ Nueva & $\begin{array}{l}\text { oreas (angostas y an- } \\
\text { chas), macayres. }\end{array}$ \\
\hline $\begin{array}{l}\text { RIVERA Y TORRES, } \\
\text { Antonio }\end{array}$ & 一 & Idem & Idem & $\begin{array}{l}\text { oreas (anchas y angos- } \\
\text { tas), bretañas. }\end{array}$ \\
\hline $\begin{array}{l}\text { ROdRÍGUEz, Fran- } \\
\text { cisco }\end{array}$ & - & especiero & C/Carnecería & $\begin{array}{l}\text { peines de boj, navajas, } \\
\text { estuches, tijeras, cordo- } \\
\text { nes de hilo, almaciga, al- } \\
\text { quitira. }\end{array}$ \\
\hline Romo, Gabriel & - & especiero & C/ Carnecería & $\begin{array}{l}\text { peines de boj, estuches, } \\
\text { cuchillos, cordones de } \\
\text { hilo, agujetas de gamu- } \\
\text { za, goma arábiga, almá- } \\
\text { ciga. }\end{array}$ \\
\hline Rosales, Lázaro & - & mercader joyas & P. de la Mar & $\begin{array}{l}\text { navajas, tijeras, peines, } \\
\text { alfileres, cordones de } \\
\text { hilo. }\end{array}$ \\
\hline Ruiz, Juan & - & especiero & - & $\begin{array}{l}\text { tijeras, peines, estuches, } \\
\text { cordones de Paris, goma } \\
\text { arábiga. }\end{array}$ \\
\hline SÁNCHEZ, Tomás & - & especiero & C/ Granada & $\begin{array}{l}\text { peines, navajas, goma } \\
\text { arábiga, alquitira, tijeras. }\end{array}$ \\
\hline $\begin{array}{l}\text { SANCHO, Miguel } \\
\text { SEPÚLVEDA, Loren- } \\
\text { zo de }\end{array}$ & - & $\begin{array}{l}\text { mercader joyas } \\
\text { mercader tienda }\end{array}$ & $\begin{array}{l}\text { C/ San Juan } \\
\text { C/ Nueva }\end{array}$ & $\begin{array}{l}\text { estuches. } \\
\text { oreas (angosta, anchas, } \\
\text { medias), bretañas. }\end{array}$ \\
\hline
\end{tabular}




\begin{tabular}{|c|c|c|c|c|}
\hline Sotro, Fabiano de & - & mercader joyería & C/ San Juan & $\begin{array}{l}\text { estuches, navajas, espe- } \\
\text { jos, cuchillos, tijeras, pei- } \\
\text { nes de boj, candados, } \\
\text { cuchillos, anillos colora- } \\
\text { dos, corales falsos de vi- } \\
\text { drio, cintas de gamuza, } \\
\text { goma arábiga, alquitira. }\end{array}$ \\
\hline $\begin{array}{l}\text { TORRES, Bernardo } \\
\text { de }\end{array}$ & - & $\begin{array}{l}\text { mercader por } \\
\text { menor }\end{array}$ & - & oreas angostas. \\
\hline TORRES, Pedro de & - & $\begin{array}{l}\text { mercader de } \\
\text { tienda }\end{array}$ & C/ Nueva & $\begin{array}{l}\text { oreas (anchas y angos- } \\
\text { tas). }\end{array}$ \\
\hline XIMÉNEZ, Melchor & - & $\begin{array}{l}\text { mercader por } \\
\text { menor }\end{array}$ & C/ Nueva & $\begin{array}{l}\text { oreas, bretañas, coto- } \\
\text { nias, alonas, macayres. }\end{array}$ \\
\hline
\end{tabular}

FUENTE: A.G.S., G.A., leg. 3504. Relación de don Jerónimo de Leira, escribano del rey, sobre los registros de mercancías de mercaderes de Francia en Málaga, 18 de octubre de 1667.

La única excepción es Málaga, puerto de moderado tráfico y que contaba con un pequeño, si bien interesante, grupo de mercaderes extranjeros introducidos en la ruta atlántico-mediterránea. De esta ciudad, la relación que nos ha llegado (cuadro II) abarca el registro únicamente de géneros de Francia en poder de cuarenta y seis mercaderes, en su mayoría vecinos del lugar -salvo en algunos casos no se indican la nacionalidad que tienen-, y ninguno de importancia, a no ser el genovés Jacinto Pesso, ya que en esta nómina no figuran los mercaderes más prestigiosos que operaban en la ciudad, quizás excluidos porque no fueran franceses o no tuviesen mercadurías de esta nación, lo cual, por otro lado, resulta inverosimil, a pesar de que no podemos demostrarlo en esta fase de nuestra investigación ${ }^{76}$. Poco más o menos se puede deducir de los datos de Tarifa (se embargan 117 pesos, es decir, 935 reales de plata), La Coruña (aquí lo confiscado se elevó a 23.940 reales de plata y 23.000 reales de vellón), Orán (el secuestro de géneros de Francia ascendió a 8.887 '5 reales de plata) y Jerez de la Frontera. En esta última ciudad los mercaderes afectados por la represalia fueron Francisco Bernal, Juan Bautista Brabato, Marcos Durán, Guillermo Heon, Luis Fabio, Juan de la Rosa y Beltrán Zubileta ${ }^{77}$.

Más interesante es la relación enviada a Madrid de los embargos efectuados en Cuenca y su partido, ya que nos ofrece una variada tipología de profesiones practicadas por súbditos de Luis XIV, aunque su permanencia en las villas donde residen los convierten en vasallos de la Corona

76 AGS, G.A., Leg. 3504. Relación de D. Jerónimo de Leira, 18 de octubre de 1667.

77 AGS, G.A., Leg. 3514. Relaciones de 25 de agosto y 9 de diciembre de 1668; Leg. 3515, Relación del 10 de noviembre de 1668. 
española. Aparecen así mercaderes, como Antonio Civite y Gabriel Torner - se ordena devolver los bienes confiscados por ser naturales de Borgoña- y Fernando de Urbina; buhoneros, cual Bernardo Essoa y Juan Berlos; agricultores -es el caso de Juan Barón-; caldereros avecindados en El Campillo y La Parrilla; aserradores - Juan Collado y consortes, en la villa de Reyllo-; y tejeros, tal que Esteban de Turbina, asociado con Miguel Castañete, en la villa de la Olmeda, con una producción de 25.000 tejas, y Juan de Chevarría, vecino de Javage, con un negocio que le permite fabricar unas 40.000 tejas ${ }^{78}$. Un grupo social, en definitiva, heterogéneo e industrioso, con un nivel de vida holgado, firmemente asentado en los lugares donde reside y capaz, con su esfuerzo, de cubrir algunas necesidades esenciales de sus convecinos, pero alejados del conjunto de grandes mercaderes franceses establecidos en los puertos mediterráneos, cantábricos, o atlánticos, cuyos beneficios mercantiles apenas si revierten en la economía nacional.

De la mayoría de las ciudades y villas carecemos de noticias, en parte porque, según la Junta de Represalias, los corregidores de los partidos se han demorado en confeccionar y remitir las relaciones solicitadas, tanto de las propiedades confiscadas como del producto de su venta ${ }^{79}$, pero también porque hasta ahora no hemos tenido la fortuna de encontrar tales documentos, algunos de los cuales se podrán localizar, tal vez, en el Archivo de Indias. No obstante, ciertas noticias permiten hacernos una idea del volumen de negocios de algunos súbditos franceses, asi como de sus relaciones comerciales y crediticias dentro o fuera de la península. Dos ejemplos aislados bastarán por ahora en tanto proseguimos nuestra investigación. El primero es el de Bernardo Militre, vecino de San Sebastián, a quien se acusa de ocultar en su casa las mercancías que ha recibido de Francia en los tres últimos meses y de haber mantenido correspondencia cifrada con el embajador francés en Madrid. El acusado se defiende alegando que es natural de Hamburgo y que hace sólo tres años que comercia por cuenta propia, relacionándose en Madrid con Carlos Agustín Corragioso, milanés, a quien enviaba algunas joyas que él recibía de París, y con Fernando Turmenier, francés, poniéndose en contacto gracias a este último con don Gabriel de Lavane, caballerizo del embajador de Francia. El embargo efectuado por el corregidor de San Sebastián en la vivienda y lonja alcanzó la cifra de 30.000 reales de plata, incluidos 20.000 reales que pretende contra Claudio Marieta por una partida de lanas que están embargadas ${ }^{80}$. Este personaje, a su vez, es igualmente

so AGS, G.A., Leg. 3506. Consulta de la Junta de Represalias, 8 de julio de 1668. 
interesante: las ciento treinta sacas de lana que se le confiscaron en $\mathrm{Na}$ varra poco antes del estallido de la guerra declara que pertenecen a don Alonso de Torres y a don Lucas Francisco de Barrionuevo, vecinos de Soria, habiendo un pleito sobre ellas pendiente en la Corte. Luego, acabada la guerra, demanda estas mercancías como propias recurriendo al consul francés, Pedro Catalán ${ }^{81}$. El otro caso que mencionábamos es el de Román Grifón, a quien se embargan sus bienes tasados en 39.079 reales de vellón: 17.839 reales por el producto de la hacienda que se le vendió en pública subasta y 21.240 reales por el precio de los bienes que no se subastaron. Además se le confiscan 1.180 reales de plata que le adeudan varios mercaderes y 276.967 reales de vellón por créditos y otros efectos contra comerciantes también franceses, algunos residentes en Madrid, otros establecidos en Sevilla y Cádiz, encontrándose entre sus clientes el cónsul francés Pedro Catalán ${ }^{82}$.

\section{DESTINO DEL IMPORTE DE LA REPRESALIA}

¿Cuál fue el destino del caudal obtenido con la represalia? Dejando al margen $8.837^{\prime} 5$ reales de plata a que ascendió el importe del secuestro en Orán, y que se aplicaron por Real Decreto de 22 de octubre de 1668 a incrementar y mejorar el ornato de la iglesia del presidio ${ }^{83}$, así como los 212.000 pesos del indulto de Galeones y Flota, una buena parte fue destinado al gasto del bolsillo secreto (206.068 reales de vellón) o, lo que es igual, a satisfacer mercedes y pensiones, pues en general estas partidas eran las que cubrían dicha bolsa, y el grueso a atender diferentes compromisos de la Real Hacienda, aunque en ningún momento se indiquen. Por último, una pequeña cantidad se empleó en retribuir con una ayuda de costa a los ministros de la Junta de Represalias. En efecto: el 29 de octubre de 1668 se aprueba entregar al conde de Ayala 6.600 reales de vellón y a cada uno de los demás ministros 3.300 reales de vellón por dicho concepto. Un mes antes, el 28 de septiembre, se autorizó conceder a cada portero de la Junta 550 reales de vellón y al oficial de la secretaría, don Vicente Constanza, 1.100 reales de la misma moneda ${ }^{84}$. No obstante, la firma de la Paz con Francia tuvo su incidencia en la recaudación conseguida durante el tiempo en que estuvo en vigor la represalia, puesto

81 Ibidem, leg. 3525. Consulta de la Junta de Represalias de 18 de septiembre de 1670.

82 Ibidem, Leg. 3534. Relación de D. Pablo de Benavente, 25 de febrero de 1671.

83 Jbidem, Leg. 3515. Consulta de la Junta, 9 de noviembre de 1668; Real Decreto de 22 de octubre de 1668 y Consulta de la Junta de 10 de noviembre de 1668.

${ }^{84}$ Ibidem, Leg. 3506. Consulta de la Junta 29 de octubre y 28 de septiembre de 1668. 
que doña Mariana de Austria, presionada por Luis XIV, decide, en conformidad con el capítulo veintidós del Tratado de los Pirineos, que se devuelva a los franceses las haciendas confiscadas "que se hallaren estantes», es decir, en su ser, no aquellas que ya fueron.vendidas siguiendo la Instrucción del 27 de agosto de 1.667, como los caballos y demás géneros que ocasionasen gastos de mantenimiento. La respuesta de la Junta de Represalias a esta decisión fue inmediata. El virrey de Valencia ya se recelaba de que, como sucedió en el pasado, los ministros de la Junta se opusieran con firmeza, y así fue. El 5 de septiembre de 1668 plantearán a la reina que no procede la devolución de las haciendas embargadas mientras no se estipule asi en el trado de paz que debe firmarse. Por otro lado señalan que los embargos realizados a los ingleses durante el conflicto armado con Cromwell jamás se devolvieron, y que así debe obrarse en la ocasión presente. Admiten, desde luego, que los interesados recurran a la Junta en demanda de justicia, pues como tribunal supremo en esta materia podrá determinar los pleitos y ajustar indultos o composiciones, pero rechazan categóricamente que se levante la mano en la represalia, aunque concluye acatando el dictamen final de la reina que no es otro que el desembargo, no admitiendo nuevas consultas sobre el particular, "por los inconvenientes de mala consecuencia que resultarían de lo contrario" ${ }^{85}$.

Con la Paz de Aquisgrán los días de existencia de la Junta de Represalias estaban contados. Aun así se mantuvo hasta bien entrado el año 1669 por dos razones fundamentales: $\left.1 .^{a}\right)$ porque restaban muchos pleitos por resolver y sólo a ella competía esta labor; 2. ${ }^{a}$ ) porque debía vigilar que el desembargo decretado por la reina se efectuase con todas las garantías posibles, sin permitir reclamaciones injustificadas. El desembargo, justo es decirlo, se produjo de inmediato, tanto en la Corona de Aragón como en la de Castilla, pero, según representa la Junta, en varios partidos los franceses a quienes se han confiscado sus bienes están ausentes o no han acudido a rescatarlos, y en estas circunstancias se procederá a venderlos en un plazo prudente de tiempo ${ }^{86}$. Por estas fechas, no obstante, el principal conflicto que tuvo la Junta fue con el presidente del Consejo de Hacienda. Doña Mariana de Austria, a instancias suyas, requirió a la Junta que le entregase todo el dinero recaudado con la represalia, urgiendo a los ministros de los partidos a que remitiesen los bienes que tenían en su poder, lo mismo que al tesorero de la Junta. Este organismo, apremiado por los despachos recibidos, no duda en quejarse

85 Ibidem, leg. 3506. Consulta de la Junta, 5 de septiembre de 1668.

86 Ibidem, leg. 3492. Consulta de la Junta 29 de octubre de 1668. 
a la reina, y asi lo hace el 31 de mayo de 1669. En su consulta asegura que ha remitido al presidente de Hacienda el caudal que estaba ingresado en la tesorería y que asimismo ha ordenado a los corregidores que hagan lo propio con el que tienen los depositarios en sus jurisdicciones. Sin embargo, representa las dificultades que ha tenido para acometer esta tarea con la celeridad exigida, debiendo emplear a tal efecto al contador, al secretario de la Cámara y al fiscal por los numerosos pleitos que aún están por concluir tanto en la Junta como en los partidos, donde sus autoridades estaban capacitadas para resolverlos hasta en una cantidad de dinero. Todo ello ha afectado su gestión, es cierto, pero la razón última -y es un argumento sostenido con insistencia- se debe únicamente al retraso en la promulgación de la represalia, de tal modo que muchos habian ocultado sus haciendas cuando ésta se decretó el 26 de agosto de 1667 produciéndose denuncias y averiguaciones que debian comprobarse, pero también a que después de la orden de desembargo convenía determinar qué bienes debian devolverse y cuáles no podían acogerse a dicha orden. Concluye sugiriendo a la reina que todos los procesos pasen al Consejo de Hacienda como se ha transferido el dinero y que se disuelva la Junta ${ }^{87}$. El 16 de julio insiste en su propuesta de disolución, representándola nuevamente el 3 de agosto y el 2 de octubre de 1669. En esta fecha doña Mariana decide que la Junta continúe en sus funciones, encargándola que fenezca los pleitos pendientes con la mayor brevedad posible y que to declarado de represalia en los partidos se comunique al presidente de Hacienda para que éste pueda aplicar su importe a las necesidades más urgentes allí donde estuviera depositado el caudal ${ }^{88}$. Todavía en el mes de diciembre la Junta estaba funcionando, mas a partir de esta fecha se pierde su rastro, pasando los pleitos pendientes al Consejo de Guerra, algunos de los cuales se arrastran durante todo el año 1670 y primeros meses de 1671, a pesar de las instancias de la reina para que finalicen, dadas las presiones que recibe del rey de Francia y del embajador español en París.

\section{CONCLUSIONES}

Tras este breve análisis del órgano ejecutivo que dirigió las acciones confiscatorias de bienes de comerciantes franceses, llegamos a una pri-

${ }^{87}$ Ibidem, leg. 3516. Consulta de la Junta 31 de mayo de 1669.

s8 Ibidem, leg. 3516. Consulta de la Junta de 2 de octubre de 1669 y respuesta de la reina al margen. 
mera conclusión, que el decreto de 23 de junio de 1635 fue, sin lugar a dudas, la base documental en que se apoyaron las decisiones de formación de la Junta de Represalias, ampliando aspectos que hacian ver que los órganos gubernamentales conocian perfectamente todo lo relativo a la estructura y despliegue comercial en los territorios de la Corona española de los mercaderes franceses, a pesar de no existir una cuantificación exacta de sus efectivos en las posesiones de la Monarquía hispánica. Por otro lado; la labor y eficacia que se proponía la reina con la creación de este órgano supremo central pronto quedaría en entredicho, porque la lentitud burocrática de los ministros en las provincias obstaculizaba el cumplimiento rápido de los decretos reales, requisito fundamental para que el éxito de las acciones contra los bienes y haciendas de súbditos franceses fuera un hecho. En tercer lugar, todo parece indicar que el esfuerzo de la Corona para colapsar el comercio francés como medida contra el enemigo no logró su propósito, debido fundamentalmente a los indultos promulgados que suavizaban la medida, lo mismo que las licencias concedidas para la venta de productos confiscados o la entrada de géneros franceses denominados de «primera necesidad", aparte de que las grandes firmas comerciales francesas no parece ser que sufrieran la represalia aun cuando carecemos de noticias a este respecto. En cuarto lugar, y para finalizar, la firma de la Paz de Aquisgrán haría fenecer a este órgano supremo, del que perdemos su rastro en diciembre de 1669, pasando todas sus competencias al Consejo de Guerra. 